Article

\title{
A Unique GSK-3 $\beta$ inhibitor B10 Has a Direct Effect on $A \beta$, Targets Tau and Metal Dyshomeostasis, and Promotes Neuronal Neurite Outgrowth
}

\author{
Xiao-Long Shi ${ }^{\dagger}$, Ning Yan ${ }^{\dagger}$, Ying-Jie Cui and Zhao-Peng Liu * \\ Key Laboratory of Chemical Biology (Ministry of Education), Department of Medicinal Chemistry, School of \\ Pharmaceutical Sciences, Shandong University, Jinan 250012, China; sxlmm0924@163.com (X.-L.S.); \\ yandayanning@163.com (N.Y.); yingjiecui@sina.cn (Y.-J.C.) \\ * Correspondence: liuzhaop@sdu.edu.cn; Tel.: +86-5318-8382-006 \\ + These authors contributed equally to this work.
}

Received: 30 January 2020; Accepted: 5 March 2020; Published: 7 March 2020

\begin{abstract}
Due to the complicated pathogenesis of Alzheimer's disease (AD), the development of multitargeted agents to simultaneously interfere with multiple pathological processes of AD is a potential choice. Glycogen synthase kinase- $3 \beta$ (GSK-3 $\beta$ ) plays a vital role in the AD pathological process. In this study, we discovered a novel $1 H$-pyrrolo[2,3-b]pyridine derivative B10 as a GSK-3 $\beta$ inhibitor that features with a quinolin-8-ol moiety to target the metal dyshomeostasis of AD. B10 potently inhibited GSK-3 $\beta$ with an $\mathrm{IC}_{50}$ of $66 \pm 2.5 \mathrm{nM}$. At the concentration of $20 \mu \mathrm{M}, \mathrm{B} 10$ increased $\beta$-catenin abundance ( $\beta$-catenin/GAPDH: $0.83 \pm 0.086$ vs. $0.30 \pm 0.016$ ), phosphorylated GSK-3 $\beta$ at Ser9 (p-GSK-3ß/GAPDH: $0.53 \pm 0.045$ vs. $0.35 \pm 0.012$ ), and decreased the phosphorylated tau level (p-tau/GAPDH: $0.33 \pm 0.065$ vs. $0.83 \pm 0.061$ ) in SH-SY5Y cells. Unlike other GSK-3 $\beta$ inhibitors, $B 10$ had a direct effect on $A \beta$ by inhibiting $A \beta_{1-42}$ aggregation and promoting the $A \beta_{1-42}$ aggregate disassociation. It selectively chelated with $\mathrm{Cu}^{2+}, \mathrm{Zn}^{2+}, \mathrm{Fe}^{3+}$, and $\mathrm{Al}^{3+}$, and targeted $\mathrm{AD}$ metal dyshomeostasis. Moreover, B10 effectively increased the mRNA expression of the recognized neurogenesis markers, GAP43, N-myc, and MAP-2, and promoted the differentiated neuronal neurite outgrowth, possibly through the GSK-3 $\beta$ and $\beta$-catenin signal pathways. Therefore, B10 is a potent and unique GSK- $3 \beta$ inhibitor that has a direct on $A \beta$ and serves as a multifunctional anti-AD agent for further investigations.
\end{abstract}

Keywords: Alzheimer's disease; A $\beta$; GSK-3 $\beta$ inhibitor; tau; metal dyshomeostasis; neurite outgrowth

\section{Introduction}

Alzheimer's disease (AD) is a progressive neurodegenerative disease and the most common dementia in old-age people [1]. Histopathologically, the hallmarks of AD include the neuronal loss, the intracellular neurofibrillary tangles (NFTs), and the extracellular senile plaques formed mainly by the amyloid $\beta$-protein $(\mathrm{A} \beta)$ aggregation $[2,3]$. At present, the FDA-approved anti-AD drugs are cholinesterase inhibitors, donepezil, rivastigmine, tacrine, galantamine, and NMDA receptor antagonist memantine $[4,5]$. These drugs provide only limited efficiency and curable drugs remain lacking. Several hypotheses are put forth to explain the causes of AD, mainly including the amyloid cascade hypothesis [6,7], tau pathology [8,9], cholinergic hypothesis [10,11], inflammatory [12,13], metal ion dyshomeostasis [14-17], and oxidative stress [18,19]; however, the exact AD etiology is still unclear. Since AD is a complicated disease with multifaceted pathogenesis, the one-drug-one-target strategy is not very effective, and therefore, the multitarget-directed ligands that simultaneously interfere with the multiple processes of AD progression are more hopeful [20-23]. 
Glycogen synthase kinase-3 (GSK-3), a serine/threonine kinase largely expressed in the central nervous system (CNS), plays important roles in metabolism, proliferation, and apoptosis [24]. The two subtypes, GSK-3 $\alpha(51 \mathrm{kDa})$ and GSK-3 $\beta(47 \mathrm{kDa})$, are $98 \%$ identical in their respective catalytic domains [25]. GSK-3 $\beta$ is predominantly the main isoform in most brain areas and the key kinase in AD responsible for the abnormal hyperphosphorylation of the microtubule-associated tau protein [26-28]. The hyperphosphorylated tau impairs the interaction between tau proteins and microtubules, leading to the detachment of tau from microtubules, destabilizing the microtubules in the neurons. The accumulation of hyperphosphorylated tau further generates paired helical filaments and subsequent aggregates to form the intracellular NFTs, one important biomarker of AD [29-31]. Moreover, increased GSK-3 $\beta$ activity may induce A $\beta$ formation through its regulation of $\gamma$-secretase in the cleavage of the amyloid-precursor protein (APP) [32]. Overactivation of GSK-3 $\beta$ is also involved in neuroinflammation, neuronal death, and apoptosis through cell signal pathways [33,34]. Both in AD model and preclinical and clinical studies, GSK-3 $\beta$ has been proven as a therapeutic target for AD [35-38].

In an effort to find potent GSK-3 $\beta$ inhibitors to target multifacets of AD [39], we report here a unique and potent GSK-3 $\beta$ inhibitor, 6-(5-(4-((pyridin-4-ylamino)methyl)phenyl)- $1 H$-pyrrolo[2,3- $b$ ] pyridin-3-yl)quinolin-8-ol (B10), which has a direct effect on $A \beta$ targets tau and metal dyshomeostasis, and promotes neuronal neurite outgrowth.

\section{Materials and Methods}

\subsection{Chemicals, Reagents, Cell Lines, and Antibodies}

All the chemicals and reagents for the synthesis of B10 were commercially available or prepared according to the cited literature. A Bruker-600 NMR spectrometer (Brucker Co., Ltd., Zurich, Switzerland) was used to measure the ${ }^{1} \mathrm{H}$ and ${ }^{13} \mathrm{C}$ NMR spectra. High-resolution mass spectra (HRMS) were determined on a 6520 QTOF instrument (Agilent Technologies Inc., Santa Clara, CA, USA) by electrospray ionization (ESI). Melting points were measured on an X-6 micromelting point apparatus (Beijing Tech. Co., Ltd., Beijing, China). Column chromatography was performed on silica gel (200-300 mesh). In cell assay, compound B10 was dissolved in 100\% dimethylsulfoxide (DMSO, Sigma, Shanghai, China) to obtain a $2 \mathrm{mM}$ stock solution, the stock solutions were diluted in culture medium at various concentrations before each treatment, and the final DMSO concentration did not exceed $0.05 \%(v / v)$. SH-SY5Y cell line was provided by JiangShu KeyGen Biotech Co., Ltd. GSK3 $\beta$ was purchased from CarnaBio (Natick, MA, USA). A $\beta_{1-42}$ (ChinaPeptides Co., Ltd., Shanghai, China) was dissolved in $100 \%$ DMSO to form a $2 \mathrm{mM}$ stock solution immediately before use. p-GSK3 $\beta$ (Ser9) antibody was obtained from Abcam China (Shanghai). The $\beta$-catenin and p-tau (Ser396) were purchased from JiangShu KeyGen Biotech Co., Ltd. All other chemicals or reagents were of analytical grade and were obtained from Sigma Chemical Co. (Shanghai, China).

\subsection{The Synthesis of 6-(5-(4-((Pyridin-4-ylamino)methyl)phenyl)-1H-Pyrrolo[2,3-b]pyridin-3-yl)quinolin-8-ol (B10)}

To a solution of 5-bromo-3-iodo-1-(phenylsulfonyl)-1H-pyrrolo[2,3-b]pyridine (1, 5.56 g, $12 \mathrm{mmol}$ ) and 8-methoxy-6-(4,4,5,5-tetramethyl-1,3,2-dioxaborolan-2-yl)quinoline (4.11 g, $14.4 \mathrm{mmol})$ in dioxane $(16 \mathrm{~mL})$ and distilled water $(0.8 \mathrm{~mL})$ was added $\mathrm{Pd}(\mathrm{dppf}) \mathrm{Cl}_{2}(0.35 \mathrm{~g}, 0.48 \mathrm{mmol})$ and $\mathrm{K}_{2} \mathrm{CO}_{3}(4.38 \mathrm{~g}$, $36 \mathrm{mmol})$. The mixture was stirred and refluxed for $2.5 \mathrm{~h}$. Distilled water $(10 \mathrm{~mL})$ was added, and the resulting solution was extracted with dichloromethane. The organic phase was washed with brine and dried over anhydrous $\mathrm{Na}_{2} \mathrm{SO}_{4}$. After filtration and evaporation, the resulting solid was dissolved in methanol $(60 \mathrm{~mL})$, and a $6 \mathrm{~mol} / \mathrm{L}$ of potassium hydroxide aqueous solution $(20 \mathrm{~mL})$ was added. After stirring at $60^{\circ} \mathrm{C}$ for $1.5 \mathrm{~h}$, the mixture was cooled to room temperature and neutralized with saturated potassium hydrogen sulfate aqueous solution. The mixture was extracted with AcOEt, washed with brine, and dried over anhydrous $\mathrm{Na}_{2} \mathrm{SO}_{4}$. After filtration and evaporation, the resulting yellowish solid was dissolved in $40 \%$ hydrobromic acid and refluxed for $24 \mathrm{~h}$. The mixture was cooled to room 
temperature and neutralized with potassium hydroxy aqueous solution. The mixture was extracted with AcOEt, washed with brine, and dried over anhydrous $\mathrm{Na}_{2} \mathrm{SO}_{4}$. After filtration and evaporation, the residue was purified by silica gel chromatography $\left(\mathrm{MeOH} / \mathrm{CH}_{2} \mathrm{Cl}_{2}=1: 30\right)$ to give $2(1.3 \mathrm{~g}$, $47.8 \%)$ as a red solid, m.p. $>240{ }^{\circ} \mathrm{C} ;{ }^{1} \mathrm{H}$ NMR $\left(400 \mathrm{MHz}, \mathrm{DMSO}_{-} \mathrm{d}_{6}\right) \delta 12.30(\mathrm{~s}, 1 \mathrm{H}), 9.90(\mathrm{~s}, 1 \mathrm{H}), 8.79(\mathrm{~d}, J=2.7 \mathrm{~Hz}$, $1 \mathrm{H}), 8.67(\mathrm{~d}, J=1.9 \mathrm{~Hz}, 1 \mathrm{H}), 8.45(\mathrm{~d}, J=8.3 \mathrm{~Hz}, 1 \mathrm{H}), 8.38(\mathrm{~d}, J=1.9 \mathrm{~Hz}, 1 \mathrm{H}), 8.15(\mathrm{~s}, 1 \mathrm{H}), 7.80(\mathrm{~s}, 1 \mathrm{H}), 7.56$ $(\mathrm{dd}, J=8.3,4.1 \mathrm{~Hz}, 1 \mathrm{H}), 7.50(\mathrm{~d}, J=1.4 \mathrm{~Hz}, 1 \mathrm{H}) ;{ }^{13} \mathrm{C}$ NMR $\left(150 \mathrm{MHz}, \mathrm{DMSO}-\mathrm{d}_{6}\right) \delta 154.03,148.05,147.83$, $143.59,138.07,136.48,133.89,130.16,129.93,127.22,122.58,119.49,114.48,114.23,112.11,110.68$; HRMS (ESI): Calcd. for $\mathrm{C}_{16} \mathrm{H}_{10} \mathrm{BrN}_{3} \mathrm{O}[\mathrm{M}+\mathrm{H}]^{+}: 340.0080$, found: 340.0086 .

To a solution of $2(910 \mathrm{mg}, 2.68 \mathrm{mmol})$ in DMF $(6 \mathrm{~mL})$ was added imidazole $(806 \mathrm{mg}, 5.35 \mathrm{mmol})$ and TBSCl (364 mg, $5.35 \mathrm{mmol})$. The mixture was stirred at room temperature for $30 \mathrm{~min}$. Distilled water $(10 \mathrm{~mL})$ was added, and the resulting mixture was extracted with AcOEt. The organic phase was washed with brine and dried over anhydrous $\mathrm{Na}_{2} \mathrm{SO}_{4}$. After filtration and evaporation, the residue was purified by silica gel chromatography (Hexane/AcOEt $=5: 1)$ to give $3(722 \mathrm{mg}, 60 \%)$ as a white solid, m.p. $232-233{ }^{\circ} \mathrm{C}^{1}{ }^{1} \mathrm{H}$ NMR $\left(600 \mathrm{MHz}, \mathrm{DMSO}_{6}\right) \delta 12.32(\mathrm{~s}, 1 \mathrm{H}), 8.82-8.78(\mathrm{~m}, 1 \mathrm{H}), 8.64(\mathrm{~d}, \mathrm{~J}=2.1 \mathrm{~Hz}$, $1 \mathrm{H}), 8.47-8.43(\mathrm{~m}, 1 \mathrm{H}), 8.38(\mathrm{~d}, J=2.1 \mathrm{~Hz}, 1 \mathrm{H}), 8.18(\mathrm{~s}, 1 \mathrm{H}), 7.94(\mathrm{~d}, J=1.7 \mathrm{~Hz}, 1 \mathrm{H}), 7.54-7.50(\mathrm{~m}, 2 \mathrm{H}), 1.06$ (s, 9H), 0.27 (s, 6H); ${ }^{13} \mathrm{C}$ NMR (150 MHz, DMSO-d 6 ) $\delta 152.77,148.46,148.08,143.63,140.62,136.40,133.43$, 130.47, 130.08, 127.36, 122.39, 119.47, 117.29, 117.01, 113.83, 112.12, 26.33, 19.09, -3.39; HRMS (ESI): Calcd. for $\mathrm{C}_{22} \mathrm{H}_{24} \mathrm{BrN}_{3} \mathrm{OSi}[\mathrm{M}+\mathrm{H}]^{+}: 454.0945$, found: 454.0953 .

To a solution of $3(150 \mathrm{mg}, 0.33 \mathrm{mmol})$ and $N$-(4-(4,4,5,5-tetramethyl-1,3,2-dioxaborolan-2-yl)benzyl) pyridin-4-amine $(205 \mathrm{mg}, 0.66 \mathrm{mmol})$ in toluene $(3 \mathrm{~mL}), \mathrm{EtOH}(1.0 \mathrm{~mL})$ and distilled water $(2.0 \mathrm{~mL})$ was added $\mathrm{Pd}\left(\mathrm{PPh}_{3}\right)_{4}(27 \mathrm{mg}, 0.023 \mathrm{mmol})$ and $\mathrm{Na}_{2} \mathrm{CO}_{3}(106 \mathrm{mg}, 1.0 \mathrm{mmol})$. The mixture was stirred at $100{ }^{\circ} \mathrm{C}$ for $6 \mathrm{~h}$. Distilled water $(5 \mathrm{~mL})$ was added, and the resulting solution was extracted with dichloromethane. The organic phase was washed with brine and dried over anhydrous $\mathrm{Na}_{2} \mathrm{SO}_{4}$. After filtration and evaporation, the resulting yellowish solid was dissolved in THF (5 mL), and TBAF $(173 \mathrm{mg}, 0.66 \mathrm{mmol})$ was added. After the mixture was stirred at room temperature for $30 \mathrm{~min}$, distilled water $(5 \mathrm{~mL})$ was added. The resulting mixture was extracted with AcOEt, and the organic phase was washed with brine and dried over anhydrous $\mathrm{Na}_{2} \mathrm{SO}_{4}$. After filtration and evaporation, the residue was purified by silica gel chromatography $(\mathrm{AcOEt} / \mathrm{MeOH}=5: 1)$ to give $\mathrm{B} 10(47 \mathrm{mg}, 32 \%)$ as a yellow solid, m.p. $>240{ }^{\circ} \mathrm{C} ;{ }^{1} \mathrm{H} \mathrm{NMR}(400 \mathrm{MHz}, \mathrm{DMSO}) \delta 12.13(\mathrm{~d}, J=2.2 \mathrm{~Hz}, 1 \mathrm{H}), 8.78(\mathrm{dd}, J=4.1,1.6 \mathrm{~Hz}$, $1 \mathrm{H}), 8.59(\mathrm{~s}, 2 \mathrm{H}), 8.43(\mathrm{dd}, J=8.4,1.5 \mathrm{~Hz}, 1 \mathrm{H}), 8.32(\mathrm{t}, J=5.6 \mathrm{~Hz}, 1 \mathrm{H}), 8.11(\mathrm{~d}, J=6.8 \mathrm{~Hz}, 2 \mathrm{H}), 8.08(\mathrm{~d}$, $J=2.6 \mathrm{~Hz}, 1 \mathrm{H}), 7.84(\mathrm{~d}, J=1.6 \mathrm{~Hz}, 1 \mathrm{H}), 7.81(\mathrm{~d}, J=8.2 \mathrm{~Hz}, 2 \mathrm{H}), 7.58-7.52(\mathrm{~m}, 2 \mathrm{H}), 7.49(\mathrm{~d}, J=8.2 \mathrm{~Hz}$, $2 \mathrm{H}), 6.78(\mathrm{~d}, J=6.8 \mathrm{~Hz}, 2 \mathrm{H}), 4.52(\mathrm{~d}, J=5.6 \mathrm{~Hz}, 2 \mathrm{H}) ;{ }^{13} \mathrm{C}$ NMR $(100 \mathrm{MHz}, \mathrm{DMSO}) \delta 171.39,155.36$, $152.92,148.17,146.64,143.55,141.50,137.43,136.92,136.16,135.35,133.50,128.86,128.10,127.42,126.81$, $125.14,125.03,121.44,116.74,113.73,113.44,109.84,44.43$; HRMS (ESI): Calcd. for $\mathrm{C}_{28} \mathrm{H}_{21} \mathrm{~N}_{5} \mathrm{O}[\mathrm{M}+\mathrm{H}]^{+}$: 444.1819 , found: 444.1835 .

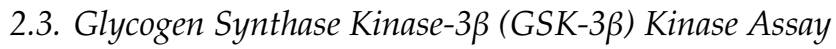

The inhibitory activity of B10 against GSK-3 $\beta$ was determined by the caliper mobility shift assay and followed the manufacturer protocol, using staurosporine as a positive control. Staurosporine or $\mathrm{B} 10$ was tested from $1 \mu \mathrm{M}$ or $5 \mu \mathrm{M}$, 3-fold dilution, in $\mathrm{IC}_{50}$ determination. The kinase reaction was done in 96-well plate (Corning, Los Altos, MA, USA). Each well was loaded with compound and GSK-3 $\beta$. The mixture was incubated at room temperature for $10 \mathrm{~min}$. The reaction was started by the addition of peptide FAM-P15 (GL Biochem, Shanghai, China) and ATP (Sigma, Shanghai, China) prepared in reaction buffer. After incubation at $28^{\circ} \mathrm{C}$ for $1 \mathrm{~h}$, a stop buffer $(25 \mu \mathrm{L})$ was added. The stopped reaction was analyzed on a LabChip EZ Reader (PerkinElmer, Shanghai, China) to give the conversion data at each concentration through the direct detection of both substrate and product via Laser-Induced Fluorescence (LIF) at $492 \mathrm{~nm}$. The $\mathrm{IC}_{50}$ values were then calculated from dose-response curves using XLfit (curve fitting software for Excel). 


\subsection{Cell Viability Assay}

SH-SY5Y human neuroblastoma cells (ATCC, CRL-2266 ${ }^{\mathrm{TM}}$ ) were cultivated in Dulbecco's modified Eagle's medium DMEM/F-12 containing of $10 \%$ FBS, $1 \%$ penicillin, and $1 \%$ streptomycin and seeded in 96-well plates (Corning, Los Altos, MA, USA) at a density of $1 \times 10^{5}$ in $100 \mu \mathrm{L}$ medium per well, respectively, and kept in $5 \% \mathrm{CO}_{2}$ atmosphere at $37^{\circ} \mathrm{C}$ for $24 \mathrm{~h}$. Compound $\mathrm{B} 10$ in different concentrations $(3.125 \mu \mathrm{M}, 6.25 \mu \mathrm{M}, 12.5 \mu \mathrm{M}$, and $25 \mu \mathrm{M})$ in $100 \mu \mathrm{L}$ medium were added, and the mixture was incubated another $24 \mathrm{~h}$. Then, $20 \mu \mathrm{L}$ of 3-(4,5-dimethyl-2-thiazolyl)-2,5-diphenyl-2H-tetrazolium bromide (MTT, $2.5 \mathrm{mg} / \mathrm{mL}$ ) was added, and the cells were incubated at $37^{\circ} \mathrm{C}$ for another $4 \mathrm{~h}$. After the addition of 200 $\mu \mathrm{L}$ DMSO to dissolve the formazan crystals, the absorbance at the wavelength of $570 \mathrm{~nm}$ was measured with a SpectraMax M5 multimode plate reader (Molecular Devices, Shanghai, China). The data were analyzed by GraphPad Prism 5 software (GraphPad Software Inc., San Diego, CA, USA).

\subsection{Western Blot Analysis on $\beta$-catenin, GSK-3 $\beta$, and Tau Phosphorylation}

SH-SY5Y cells were cultured in 90\% DMEM/F12 and 10\% PBS at a humidified atmosphere with $5 \% \mathrm{CO}_{2} .1 \times 10^{6}$ cells were seeded in 12-well plates (Corning, Los Altos, MA, USA) and incubated with compound at the indicated concentrations for $1 \mathrm{~h}$ and $\mathrm{A} \beta_{25-35}$ (Sigma, Shanghai, China) for another $6 \mathrm{~h}$. After the SH-SY5Y cells were lysed with RIPA buffer, total protein concentration was determined by Bradford method. Cellular protein was mixed with an equal volume of SDS (sodium dodecyl sulfate) loading buffer (JiangShu KeyGen Biotech, Nanjing, China) and separated by electrophoresis (Bio-rad Power Supplies Basic, Shanghai, China) in polyacrylamide gel. Proteins were transferred from acrylamide gels to nitrocellulose membranes (Amersham Italia, Milan, Italy) and blocked in a blocking buffer (PBS, $5 \%$ nonfat milk) for 1.5 to $2 \mathrm{~h}$ at $20{ }^{\circ} \mathrm{C}$. After overnight incubation at $4{ }^{\circ} \mathrm{C}$ with antibody p-GSK3 $\beta$-Ser 9 (KaiTai-Bio, Hongzhou, China), or p-tau Ser396 (Abcam, Shanghai, China), or $\beta$-catenin antibody (Cell Signaling Technology, Danvers, MA, USA), and GAPDH (Santa Cruz Biotechnology, Shanghai, China), the blots were washed in Tween 20-TBS (TBST, JiangShu KeyGen Biotech, Nanjing, China) for 20 min and then incubated with secondary antibody (IgG-HRP; JiangShu KeyGen Biotech, Nanjing, China) for $1 \mathrm{~h}$ at room temperature. The blots were washed by TBST for $20 \mathrm{~min}$ and incubated with ECL chemiluminescent reagent (JiangShu KeyGen Biotech, Nanjing, China) for $3 \mathrm{~min}$. Quantification of pixel intensity was done using gel imaging system (SYNGENE G:BOX/iChemi XR5, ISS, San Diego, CA, US) and Gel-Pro32 software (Media Cybernetics, Bethesda, MD, USA). GAPDH was used as an internal control.

\subsection{Metal Chelation}

Compound B10 was dissolved in $100 \%$ methanol to form a $20 \mu \mathrm{M}$ solution. The salt $(\mathrm{NaCl}, \mathrm{KCl}$, $\mathrm{CaCl}_{2}, \mathrm{MgCl}_{2}, \mathrm{FeSO}_{4}, \mathrm{ZnCl}_{2}, \mathrm{CuCl}_{2}$, and $\mathrm{AlCl}_{3}$ ) was dissolved in $100 \%$ methanol to give a $40 \mu \mathrm{M}$ metal ion solution. A mixture of the B10 solution $(20 \mu \mathrm{M}, 2 \mathrm{~mL})$ with the metal ion solution $(40 \mu \mathrm{M}, 2 \mathrm{~mL})$ or with $100 \%$ methanol $(2 \mathrm{~mL})$ was incubated at $25^{\circ} \mathrm{C}$ for $30 \mathrm{~min}$. The UV spectra of B10 alone or in the presence of each metal ion were recorded by TU-1901 ultraviolet-visible spectrophotometer (Beijing PurSee General Co, Ltd, Beijing, China) at the wavelength ranging from 200 to $500 \mathrm{~nm}$, respectively.

\subsection{Amyloid $\beta$-Peptide 1-42 (A $\left.\beta_{1-42}\right)$ Aggregation and $C u^{2+}$-Induced $A \beta_{1-42}$ Aggregation Assay}

The $2 \mathrm{mM} \mathrm{A} \beta_{1-42}$ stock solution $(10 \mu \mathrm{L})$ was diluted with $20 \mu \mathrm{M}$ HEPES $(\mathrm{pH}=6.6,150 \mu \mathrm{M} \mathrm{NaCl}$, $490 \mu \mathrm{L}$ ) into a $40 \mu \mathrm{M}$ solution. Compound B10 and the positive control curcumin (Sigma, Shanghai, China) were dissolved in $100 \%$ DMSO to form a $2 \mathrm{mM}$ stock solution. The stock solution ( $10 \mu \mathrm{L})$ of B10 or curcumin was diluted with $20 \mu \mathrm{M}$ HEPES $(490 \mu \mathrm{L})$ into a $40 \mu \mathrm{M}$ solution. $\mathrm{CuCl}_{2}$ was dissolved in HEPES to give a $40 \mu \mathrm{M}$ solution. Thioflavin T (ThT; Sigma, Shanghai, China) was dissolved in $50 \mathrm{mM}$ glycine- $\mathrm{NaOH}$ buffer $(\mathrm{pH}=8.0)$ to form a $5 \mu \mathrm{M}$ stock solution. $\mathrm{A} \beta_{1-42}(20 \mu \mathrm{L}, 40 \mu \mathrm{M}), \mathrm{A} \beta_{1-42}$ $(20 \mu \mathrm{L}, 40 \mu \mathrm{M})$ plus $\mathrm{CuCl}_{2}(20 \mu \mathrm{L}, 40 \mu \mathrm{M})$, and $\mathrm{A} \beta_{1-42}(20 \mu \mathrm{L}, 40 \mu \mathrm{M})$, and $\mathrm{CuCl}_{2}(20 \mu \mathrm{L}, 40 \mu \mathrm{M})$ in the presence of compound $(40 \mu \mathrm{L}, 40 \mu \mathrm{M})$, were incubated at $37^{\circ} \mathrm{C}$ for $24 \mathrm{~h}$. After that, a $5 \mu \mathrm{M}$ ThT 
stock solution was added to each well with a final volume of $200 \mu \mathrm{L} /$ well and further incubated for 5 min. The fluorescence was measured on a Tecan Infinite 200 PRO (Tecan Trading Co., Ltd., Shanghai, China) at excitation and emission wavelengths of $450 \mathrm{~nm}$ and $490 \mathrm{~nm}$, respectively. The inhibition rate is calculated based on the fluorescence differences by the formula: [1-(FL $\left.\left.\mathrm{F}_{\text {compound }}-\mathrm{FL}_{\mathrm{blank}}\right) / \mathrm{FL}_{\mathrm{control}}\right] \times$ 100 , both for the aggregation and disaggregation assay. The HEPES solution containing only compound was used as a blank group; the $\mathrm{A} \beta_{1-42}$ or $\mathrm{A} \beta_{1-42} / \mathrm{CuCl}_{2}$ was the control group.

\subsection{Disaggregation of $A \beta_{1-42}$ Aggregation and $C u^{2+}$-Induced $A \beta_{1-42}$ Aggregation}

The positive control clioquinol (CQ, Santa Cruz Biotechnology, Shanghai, China) was dissolved in $100 \%$ DMSO to form a $2 \mathrm{mM}$ stock solution. The stock solution of CQ $(10 \mu \mathrm{L})$ was diluted with $20 \mu \mathrm{M}$ HEPES $(\mathrm{pH}=6.6,150 \mu \mathrm{M} \mathrm{NaCl}, 490 \mu \mathrm{L})$ into a $40 \mu \mathrm{M}$ solution. $\mathrm{A} \beta_{1-42}(20 \mu \mathrm{L}, 40 \mu \mathrm{M})$ or $\mathrm{A} \beta_{1-42}$ $(20 \mu \mathrm{L}, 40 \mu \mathrm{M})$ plus $\mathrm{CuCl}_{2}(20 \mu \mathrm{L}, 40 \mu \mathrm{M})$ was incubated in black, opaque 96-well plates (Corning, Los Altos, MA, USA) at $37^{\circ} \mathrm{C}$ for $24 \mathrm{~h}$ to form $\mathrm{A} \beta_{1-42}$ aggregates. After that, $40 \mu \mathrm{L} \mathrm{HEPES} \mathrm{or} \mathrm{B10}(40 \mu \mathrm{L}$, $40 \mu \mathrm{M})$ or CQ $(40 \mu \mathrm{L}, 40 \mu \mathrm{M})$ was added and incubated for another $24 \mathrm{~h}$. A $5 \mu \mathrm{M}$ ThT stock solution was added to each well with a final volume of $200 \mu \mathrm{L} /$ well. After incubation for $5 \mathrm{~min}$, the fluorescence was measured on a Tecan Infinite 200 PRO (Tecan Trading Co., Ltd., Shanghai, China) at excitation and emission wavelengths of $450 \mathrm{~nm}$ and $490 \mathrm{~nm}$, respectively.

Aggregation and disaggregation of $A \beta_{1-42}$ during the ThT assays were confirmed by transmission electron microscopy (TEM). Briefly, aliquots $(10 \mu \mathrm{L})$ of the samples were taken from the wells and placed on a carbon-coated copper grid for $20 \mathrm{~min}$. Each grid was stained with aqueous phosphotungstic acid $(2 \%, 10 \mu \mathrm{L})$ for $1 \mathrm{~min}$. After draining the excess staining solution, the specimen was transferred for imaging by TEM (Hitachi HT7700, Tokyo, Japan).

\subsection{Neuronal Neurite Outgrowth Assay and Quantitative Real-Time Reverse Transcription-PCR (RT-PCR)}

SH-SY5Y cells were cultivated in DMEM containing 10\% FBS, $100 \mathrm{IU} / \mathrm{L}$ penicillin, and $10 \mu \mathrm{g} / \mathrm{mL}$ streptomycin and seeded in 96-well plates (Corning, Los Altos, MA, USA) at a density of $5 \times 10^{3}$ in $100 \mu \mathrm{L}$ medium per well and kept in $5 \% \mathrm{CO}_{2}$ atmosphere at $37^{\circ} \mathrm{C}$ for $24 \mathrm{~h}$. After that, compound (RA or B10) diluted in medium $(100 \mu \mathrm{L})$ was added and cultivated for $72 \mathrm{~h}$. The morphology of neurite outgrowth was examined under an inverted microscope $(2 \times 100$; Olympus, Tokyo, Japan).

After the SH-SY5Y cells were cultivated for $24 \mathrm{~h}$, total RNA was extracted using TRIzol reagent (Thermo Fisher Scientific Inc., Carlsbad, CA, USA) according to the manufacturer directions. RNA was quantified by measuring the absorbance at $260 \mathrm{~nm}$, and purity was determined by valuating the absorbance 260/280 nm ratio. The absorbance was measured by Shimadzu UV-2450 (Shimadzu China Co. Ltd., Shanghai, China). PrimeScript RT Master Mix (Takara Bio Inc., Shiga, Japan) was used to synthesize the first-strand cDNA. The determination of mRNA levels was determined by using SYBR Green Master Mix (Takara Bio Inc., Shiga, Japan). Primer sequences were as follows: GAP43, GAGCAGTTCGACCTAGTCCTT (upstream), GGTTGCGGCCTTATGAGCTT (downstream); N-myc, AGTTTGACTCGCTACAGCCC (upstream), GCAGCAGCTCAAACTTCTTCC (downstream); MAP2, TCTGCACACTCACATCCACC (upstream), CTGTGACCCATGCTCTCCAA (downstream); GAPDH, CAAATTCCATGGCACCGTCA (upstream), AGCATCGCCCCACTTGATTT (downstream). The GAPDH mRNA was used as the reference.

\subsection{Molecular Docking}

The protein structures of GSK-3 $\beta$ (PDB ID: 5F95) and A $\beta_{1-42}$ monomer (PDB codes: 1IYT) were obtained from the RCSB Protein Date Bank. The protein structure was prepared with the SYBYL-X suite (version 2.1.1, Tripos). For GSK-3 $\beta$, the ligand was first extracted from the protein, and then the hydrogen atoms and charges were added. The extracted ligand was used as a standard to generate the protomol. For $A \beta_{1-42}$, hydrogen atoms were added to the crystal and charges were added to biopolymer by AMBER7 FF99 force field. The protomol was generated according to residues 13-27 (HHQKLVFFAEDVGSN). The 3D structures of B10 were prepared by the Sketch module of Sybyl 
followed by energy minimization using the Tripos force field. The Surflex-dock module was used for the simulations, and the related parameters implied in the program were kept at default.

\subsection{Statistics}

Qualitative data including the immunoblots and images are representatives of at least three independent experiments and expressed as means \pm SD. Statistical differences between two groups were determined by the two-tailed unpaired or paired Student t-test. $p<0.05$ is considered significantly different.

\section{Results}

\subsection{Design and Synthesis of B10}

Metal dyshomeostasis plays important roles in AD pathogenesis by preceding or inducing NFTs, senile plaques, and reactive oxygen species (ROS) [14-17]. $\mathrm{Cu}^{2+}, \mathrm{Zn}^{2+}$, and $\mathrm{Fe}^{2+}$ are known to excessively exist in the senile plaques $[17,40]$. As one of the main cationic elements in plaque formation, copper ion binds to $A \beta$, promoting its accumulation and inducing ROS generation and oxidative stress $[41,42]$. The generated ROS may in turn produce modified $A \beta$ species that favor $A \beta$ aggregation and resist disaggregation $[43,44]$. 8-Hydroxyquinoline is a bidentate metal chelator and one of the most-used metal-chelating scaffolds in the design of multitarget $\mathrm{AD}$ agents [41,45]. To target the multifacets of $\mathrm{AD}$, we designed novel pyrrolo[2,3-b]pyridinyl-based GSK-3 $\beta$ inhibitors incorporating 8-hydroxyquinoline motif to also target AD metal dyshomeostasis. The synthesis of B10 is shown in Figure 1.

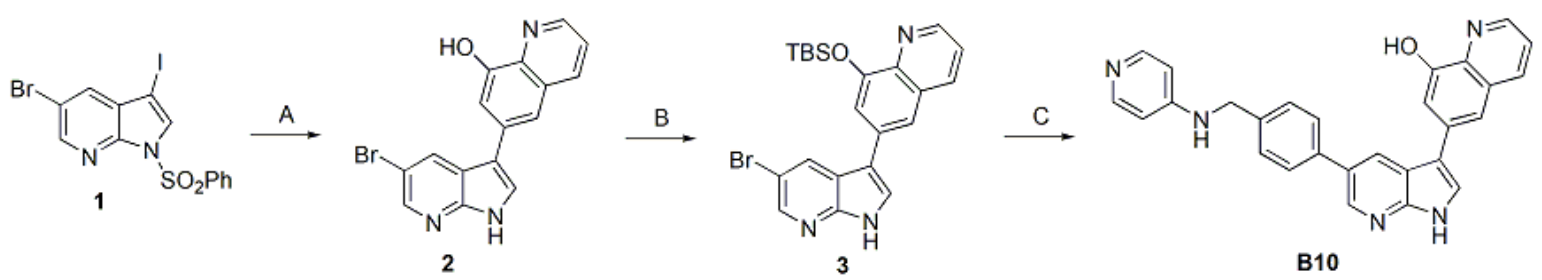

Figure 1. Synthesis of B10. Reagents and conditions: (A) (1) 8-methoxy-6-(4,4,5,5-tetramethyl-1,3, 2-dioxaborolan-2-yl)quinoline, $\mathrm{Pd}(\mathrm{dppf}) \mathrm{Cl}_{2}, \mathrm{~K}_{2} \mathrm{CO}_{3}$, dioxane/ $\mathrm{H}_{2} \mathrm{O}$, reflux, $2.5 \mathrm{~h}$; (2) $\mathrm{KOH}, \mathrm{MeOH}, 60{ }^{\circ} \mathrm{C}$, $1.5 \mathrm{~h}$; (3) 40\% HBr, reflux, 24 h; (B) TBSCl, imidazole, DMF, 0.5 h; (C) (1) N-(4-(4,4,5,5-tetramethyl-1,3, 2-dioxaborolan-2-yl)benzyl)pyridin-4-amine, $\mathrm{Pd}\left(\mathrm{PPh}_{3}\right)_{4}, \mathrm{Na}_{2} \mathrm{CO}_{3}$, toluene, $\mathrm{EtOH}, \mathrm{H}_{2} \mathrm{O}, 100{ }^{\circ} \mathrm{C}, 6 \mathrm{~h}$; (2) TBAF, THF, $0.5 \mathrm{~h}$.

5-Bromo-3-iodo-1-(phenylsulfonyl)-1H-pyrrolo[2,3-b]pyridine (1) was easily prepared by the reaction of 5-bromo-3-iodo- $1 H$-pyrrolo[2,3-b]pyridine with benzenesulfonyl chloride according to reported methods [46]. Suzuki coupling of 1 with 8-methoxy-6-(4,4,5,5-tetramethyl-1,3,2-dioxaborolan-2-yl) quinoline [47] catalyzed by $\mathrm{Pd}(\mathrm{dppf}) \mathrm{Cl}_{2}$, followed by the removal of benzenesulfonyl protective group under basic conditions and the subsequent removal of the ether methyl group by hydrobromic acid, generated the 8-hydroxyquinoline derivative 2 in $47.8 \%$ yield (3 steps). The reaction of 2 with tert-butyldimethylsilyl chloride (TBSCl) in DMF in the presence of imidazole gave the TBS ether 3 in 60\% yield. The Suzuki coupling of 3 with $N$-(4-(4,4,5,5-tetramethyl-1,3,2-dioxaborolan-2-yl)benzyl) pyridin-4-amine catalyzed by $\mathrm{Pd}\left(\mathrm{PPh}_{3}\right)_{4}$ in the presence of $\mathrm{Na}_{2} \mathrm{CO}_{3}$ in ethanol and water at $100{ }^{\circ} \mathrm{C}$, followed by the removal of the TBS protective group with tetra- $n$-butylammonium Fluoride (TBAF), furnished B10 in $32 \%$ yield.

\subsection{B10 Is a Potent GSK-3 $\beta$ In Vitro Inhibitor}

Staurosporine is a prototypical ATP-competitive kinase inhibitor that potently inhibits GSK-3 $\beta$ with a reported $\mathrm{IC}_{50}$ value of $15 \mathrm{nM}$ [48]. In the caliper mobility shift assay, staurosporine was used as a positive control with a determined $\mathrm{IC}_{50}$ of $16.5 \pm 1.2 \mathrm{nM}(\mathrm{n}=3)$. B10 was found to be a potent GSK-3 $\beta$ inhibitor with an $\mathrm{IC}_{50}$ of $66 \pm 2.5 \mathrm{nM}$ (Figure $2 \mathrm{~A}$ ). 
$\mathbf{A}$

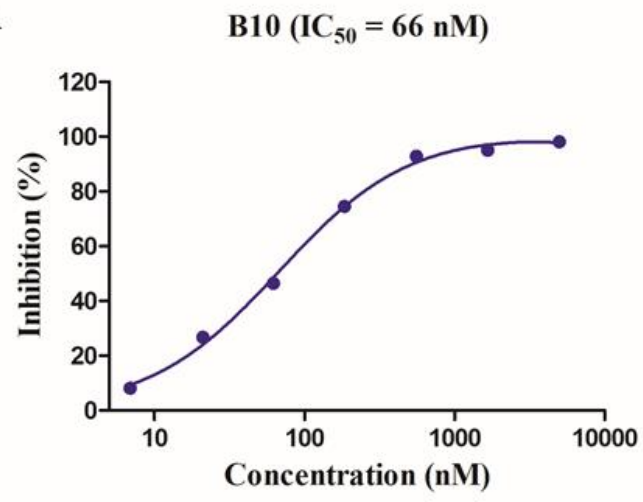

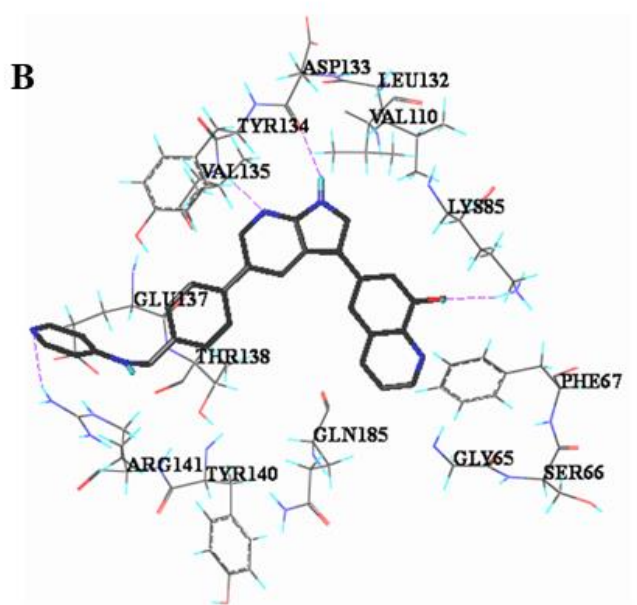

Figure 2. (A) The inhibition curve of B10 against GSK-3 $\beta$; (B) the predicted binding mode of B10 in the ATP binding pocket of GSK-3 $\beta$ (PDB ID: 5F95).

To explore the possible interaction mode of the B10 with GSK-3 $\beta$, molecular docking studies were performed on SYBYL based on the reported GSK-3 $\beta$ structure (PDB ID: 5F95) [49]. As shown in Figure 2B, B10 fitted well into the ATP binding pocket of GSK-3 $\beta$ : the pyrrolo[2,3- $b$ ]pyridinyl moiety formed two hydrogen bonds with VAL135 and ASP133 in the hinge region; the 8-hydroxyquinoline scaffold occupied one hydrophobic pocket and made crucial hydrogen bonding with LYS85 through its 8-hydroxyl group; the pyridin-4-amine portion fell into another hydrophobic pocket and formed hydrogen bond interaction with ARG141 through the pyridine nitrogen atom. All these hydrophobic interactions and hydrogen bonds may contribute to its high potency against GSK-3 $\beta$.

\subsection{B10 Regulates GSK-3 $\beta$ and $\beta$-catenin Signal Pathways and Inhibits Tau Phosphorylation in Human Neuroblastoma SH-SY5Y Cells}

Since B10 showed high potency in the inhibition of GSK-3 $\beta$ at the enzymatic level, we further investigated its effect on $\mathrm{SH}-\mathrm{SY} 5 \mathrm{Y}$ cells by Western blot assays. $\mathrm{LiCl}$ is a non-ATP competitive inhibitor of GSK-3 $\beta$. At the concentration of $5 \mathrm{mM}, \mathrm{LiCl}$ greatly increased the levels of GSK-3 $\beta$ phosphorylated

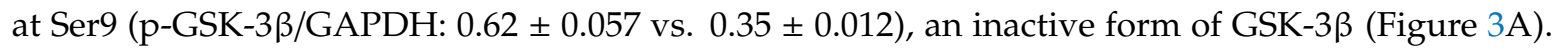
Treatment with B10 at $10 \mu \mathrm{M}$ and $20 \mu \mathrm{M}$ dose-dependently increased the phospho-GSK-3 $\beta$ level in comparison with the control group, and the p-GSK-3 $\beta /$ GAPDH ratio was $0.44 \pm 0.037$ and $0.53 \pm$ 0.045 , respectively.

$\beta$-Catenin is a Wnt signaling component that is destabilized upon that activation of GSK-3 $\beta$ [50]. In agreement with its inhibitory activity of GSK-3 $\beta$ on SH-SY5Y cells, B10 increased $\beta$-catenin abundance in a dose-dependent manner (Figure 3B). After the treatment with B10 at the concentrations of $5 \mu \mathrm{M}, 10 \mu \mathrm{M}$, and $20 \mu \mathrm{M}$, the $\beta$-catenin/GAPDH ratio increased from $0.30 \pm 0.016$ of the control to $0.46 \pm 0.033,0.57 \pm 0.051$, and $0.83 \pm 0.086$, respectively.

Elevated levels of hyperphosphorylated tau are highly related to the formation of NFTs in the brains of AD patients. When SH-SY5Y cells were treated with $20 \mu \mathrm{M} \mathrm{A} \beta_{25-35}$ for $6 \mathrm{~h}$, the phosphorylation of tau protein at Ser396 increased significantly with a p-tau/GAPDH ratio $0.83 \pm 0.061$ (Figure 3C). Treatment with B10 at $5 \mu \mathrm{M}, 10 \mu \mathrm{M}$, and $20 \mu \mathrm{M}$ resulted in a decrease in tau phosphorylation level in a concentration-dependent way (p-tau/GAPDH: $0.65 \pm 0.029,0.40 \pm 0.061$, and $0.33 \pm 0.065$ ). At the concentration of $20 \mu \mathrm{M}$, more than half of the hyperphosphorylated tau was reduced by pretreatment with B10. 
A
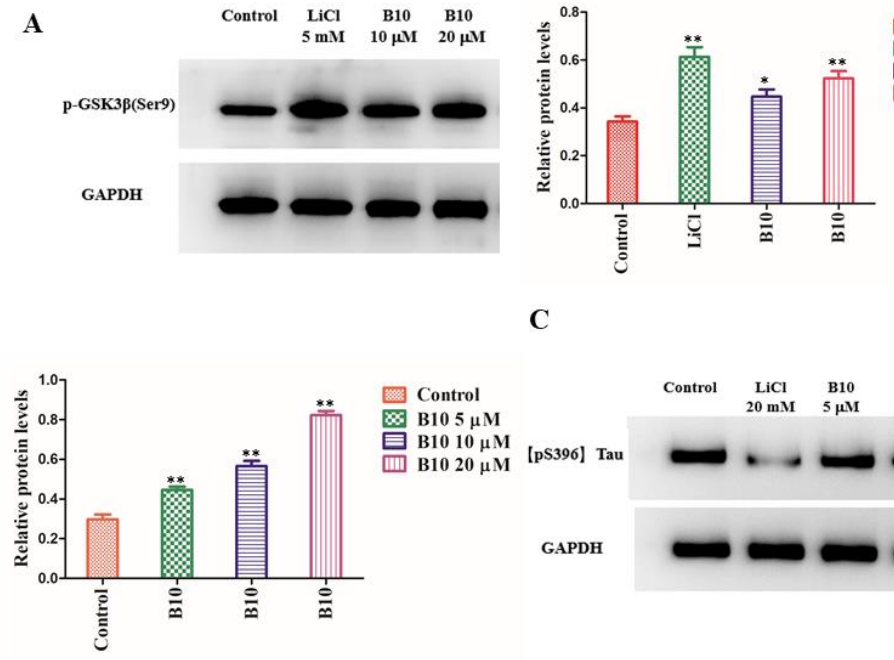

C

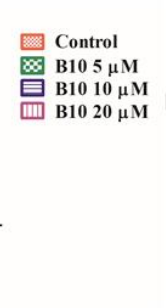

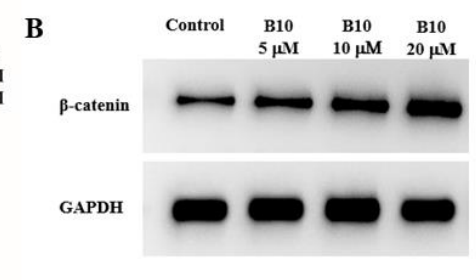

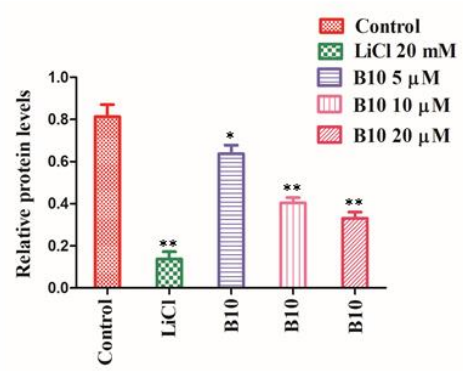

Figure 3. B10 is a potent GSK-3 $\beta$ inhibitor in SH-SY5Y cells. (A) The effect of B10 on phosphorylation of GSK-3 $\beta$ at the site of Ser9; (B) the effect of B10 on $\beta$-catenin abundance; (C) the effect of B10 on phosphorylation of tau at Ser396. Protein expression was detected by immunoblot analysis with a specific antibody. Values represent the mean $\pm \mathrm{SD}(\mathrm{n}=3) ;{ }^{*} p<0.05,{ }^{* *} p<0.01$ vs. control.

\subsection{B10 Selectively Chelates with $\mathrm{Fe}^{2+}, \mathrm{Zn}^{2+}, \mathrm{Cu}^{2+}$, and $\mathrm{Al}^{3+}$}

Compound B10 was evaluated for its chelating ability with $\mathrm{Na}^{+}, \mathrm{K}^{+}, \mathrm{Mg}^{2+}, \mathrm{Fe}^{2+}, \mathrm{Zn}^{2+}, \mathrm{Ca}^{2+}$, $\mathrm{Cu}^{2+}$ and $\mathrm{Al}^{3+}$ by the UV-vis spectroscopy assay [51]. When $\mathrm{Na}^{+}, \mathrm{K}^{+}, \mathrm{Mg}^{2+}$, or $\mathrm{Ca}^{2+}$ was mixed with B10, the electronic spectra showed no obvious changes (Figure 4A,B), indicating B10 has little chelating ability with these metal ions. When $\mathrm{FeSO}_{4}$ was mixed with B10, a red shift from $262 \mathrm{~nm}$ to $280 \mathrm{~nm}$ were observed, and a new peak appeared at $310 \mathrm{~nm}$ (Figure $4 \mathrm{~B}$ ). In the presence of $\mathrm{ZnCl}_{2}$, $\mathrm{CuCl}_{2}$, or $\mathrm{AlCl}_{3}$, new absorptions at 311, 304, and $302 \mathrm{~nm}$ were observed, respectively. These results indicated that B10 could chelate effectively with these ions. There is a controversy over the role of $\mathrm{Al}^{3+}$, increasing evidence supports the implication of it in the development of AD [52]. The selective chelating ability of $\mathrm{B} 10$ toward $\mathrm{Fe}^{2+}, \mathrm{Zn}^{2+}, \mathrm{Cu}^{2+}$ and $\mathrm{Al}^{3+}$ makes it as a potential agent targeting metal dyshomeostasis in AD.
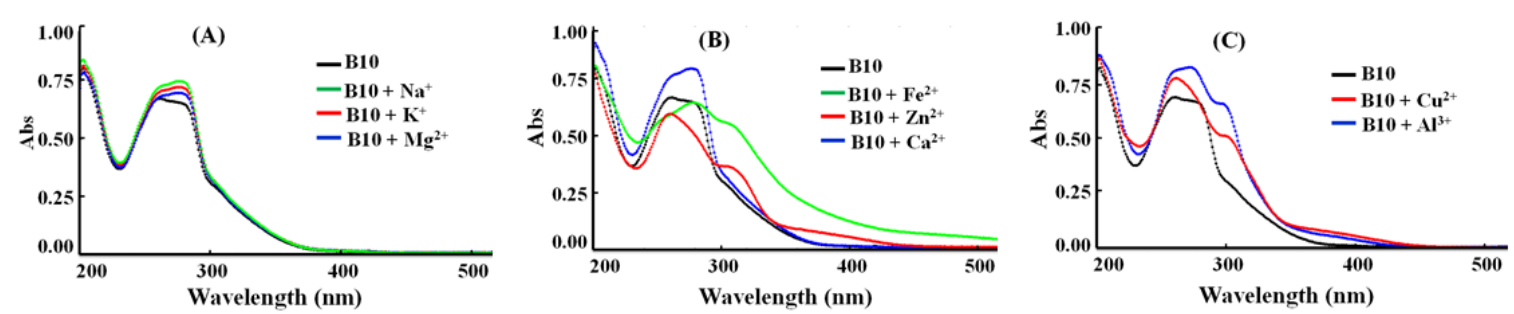

Figure 4. UV-vis spectra of $\mathrm{B} 10(20 \mu \mathrm{M})$ alone or in the presence of metal ions $(40 \mu \mathrm{M})$ in $\mathrm{CH}_{3} \mathrm{OH}$. (A) $\mathrm{Na}^{+}, \mathrm{K}^{+}, \mathrm{Mg}^{2+} ;$ (B) $\mathrm{Fe}^{2+}, \mathrm{Zn}^{2+}, \mathrm{Ca}^{2+} ;$ (C) $\mathrm{Cu}^{2+}, \mathrm{Al}^{3+}$.

\subsection{B10 Has a Direct Effect on $A \beta_{1-42}$ Aggregation and Disaggregation of A $\beta$ Aggregates and Affects} $C u^{2+}$-Induced $A \beta_{1-42}$ Aggregation and $C u^{2+}-A \beta_{1-42}$ Aggregates Disaggregation

To determine whether $\mathrm{B} 10$ has a direct effect on the inhibition the aggregation of $\mathrm{A} \beta$ monomers, we incubated monomeric $\mathrm{A} \beta_{1-42}(20 \mu \mathrm{L}, 40 \mu \mathrm{M})$ with $\mathrm{B} 10(20 \mu \mathrm{L}, 40 \mu \mathrm{M})$ and quantified the amount of $\mathrm{A} \beta$ aggregates by thioflavin T (ThT) fluorescence assay with curcumin (cur) as a positive control [53]. As shown in Figure 5A, B10 effectively blocked the A $\beta$ aggregate formation with an inhibitory rate of $55.1 \pm 3.0 \%$, more potent than curcumin $(38.1 \pm 6.3 \%)$. This was confirmed by TEM images (Figure 5B). In addition, when B10 was incubated with solutions containing preformed A $\beta$ aggregates, 
B10 effectively disaggregated the $A \beta$ fibrils, reducing the amount of $A \beta$ aggregates by $61.8 \pm 4.1 \%$, much more potent than curcumin $(35.3 \pm 2.6 \%)$ (Figure $5 \mathrm{C}$ ).

$\mathbf{A}$

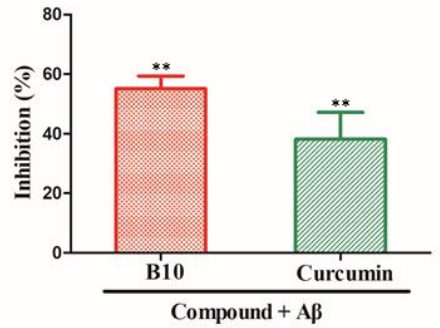

B

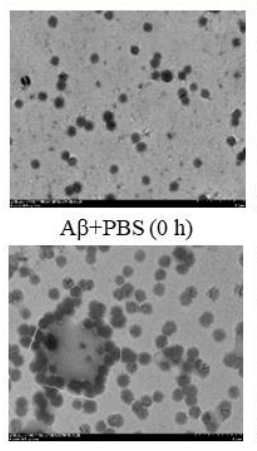

$\mathbf{A} \beta+\mathbf{B 1 0}(24 \mathrm{~h})$
C

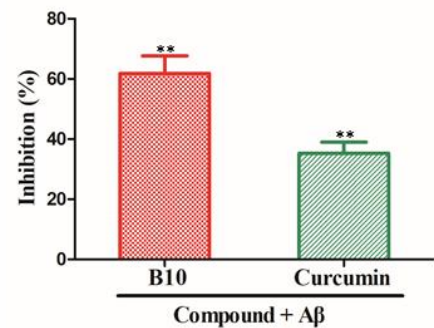

D

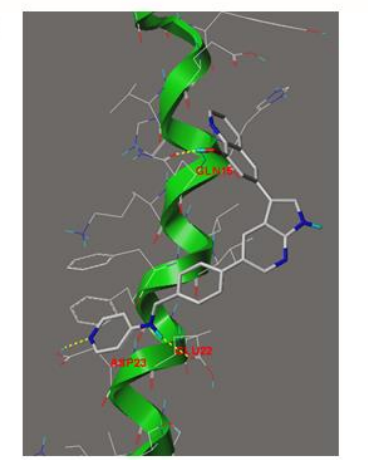

$\mathbf{E}$

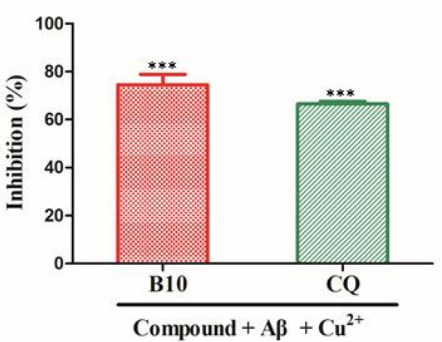

$\mathbf{F}$

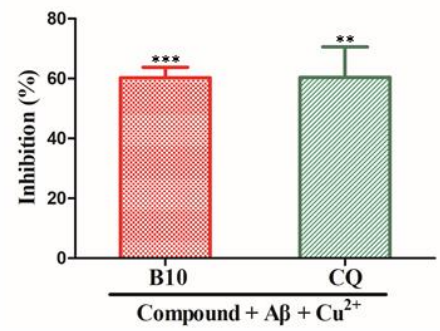

Figure 5. (A) Effect of $B 10$ on the monomeric $A \beta_{1-42}$ aggregation; (B) TEM images of $A \beta_{1-42}$ aggregation; (C) effect of $B 10$ on $A \beta_{1-42}$ aggregates disaggregation; (D) molecular docking of $B 10$ with $A \beta_{1-42}$ (PDB code: 1IYT); (E) effect of $B 10$ on $\mathrm{Cu}^{2+}$-induced $A \beta_{1-42}$ aggregation; (F) effect of $\mathrm{B} 10$ on $\mathrm{Cu}^{2+}-\mathrm{A} \beta_{1-42}$ aggregates disaggregation. In aggregation assay, $A \beta_{1-42} /$ compound $(1 / 1)$ or $A \beta_{1-42} / \mathrm{Cu}^{2+} /$ compound $(1 / 1 / 2)$ was in HEPES at $37{ }^{\circ} \mathrm{C}$ for $24 \mathrm{~h}$. In disaggregation assay, after $\mathrm{A} \beta_{1-42}$ or $\mathrm{A} \beta_{1-42} / \mathrm{Cu}^{2+}$ was incubated for $24 \mathrm{~h}$ to form aggregates, compounds were then added and further incubated for $24 \mathrm{~h}$. Values are reported as the mean $\pm \mathrm{SD}$ of three independent experiments. ${ }^{* * *} p<0.001,{ }^{* *} p<0.01 \mathrm{vs}$. $\mathrm{A} \beta_{1-42}$ or $\mathrm{A} \beta_{1-42} / \mathrm{Cu}^{2+}$ alone.

To elucidate why $B 10$ affects $A \beta_{1-42}$ aggregation and disaggregation, docking simulations were carried out based on the resolved structure of the peptide in its $\alpha$ helix form (PDB code: 1IYT). In A $\beta_{1-42}$ monomer, the self-recognition hydrophobic core " ${ }^{16} \mathrm{KLVFFA}^{21 "}$ is located in the central region of the $A \beta$ peptide and is known as the key amyloidogenic sequence that initiates the $A \beta-A \beta$ interaction [54]. As shown in Figure 5D, B10 interacted with the "16 KLVFFA" ${ }^{21 "}$ amyloid region. The pyridyl nitrogen atom formed a hydrogen bond with Asp23, and the pyridine ring interacted with Phe20 through $\pi-\pi$ stacking. The 4-pyridylamino $\mathrm{NH}$ served as a hydrogen bond donor to interact with Glu22. The hydroxyl group in the 8-hydroxyquinoline moiety formed a hydrogen bond with Gln 15 . All of these interactions may contribute to the direct effect of $B 10$ on $A \beta_{1-42}$ aggregation and disaggregation.

$\mathrm{Cu}^{2+}$ is a well-known metal ion that modulates the $A \beta$ aggregation and toxicity [42]. To validate whether B10 could target metal dyshomeostasis, the mixtures of $\mathrm{A} \beta_{1-42}(20 \mu \mathrm{L}, 40 \mu \mathrm{M}), \mathrm{CuCl}_{2}(20 \mu \mathrm{L}$, $40 \mu \mathrm{M})$, and B10 or CQ $(40 \mu \mathrm{L}, 40 \mu \mathrm{M})$ were incubated at $37^{\circ} \mathrm{C}$ for $24 \mathrm{~h}$ and detected by ThT assay. In the presence of $\mathrm{Cu}^{2+}$, the fluorescence intensity of the $\mathrm{A} \beta_{1-42}$ and $\mathrm{Cu}^{2+}$ mixture significantly increased over 1.2-fold in comparison with that of $A \beta_{1-42}$ alone. As shown in Figure 5E, the positive control $C Q$, a known nonspecific copper/zinc chelator that can reduce $A \beta$ deposits and improve learning and memory capacities of APP transgenic mice [41], inhibited the $\mathrm{Cu}^{2+}$-induced $\mathrm{A} \beta_{1-42}$ aggregation by $66.5 \pm 0.9 \%$. B10 was more potent than CQ with an inhibitory rate of $74.6 \pm 3.5 \%$.

As an effective agent targeting AD copper homeostasis, the chelator is required not only to inhibit $\mathrm{Cu}^{2+}$-induced $\mathrm{A} \beta$ aggregation but also to have the ability to extract the copper ion from the aggregates and promote their disaggregation. To evaluate the activity of $\mathrm{B} 10$ to disaggregate $\mathrm{Cu}^{2+}$-induced $\mathrm{A} \beta_{1-42}$ 
aggregation, $\mathrm{A} \beta_{1-42}$ and $\mathrm{Cu}^{2+}$ were first incubated at $37^{\circ} \mathrm{C}$ for $24 \mathrm{~h}$ to form $\mathrm{A} \beta_{1-42}$ fibrils, $\mathrm{B} 10$ or $\mathrm{CQ}$ was then added and incubated for another $24 \mathrm{~h}$. As shown in Figure 5F, B10 showed a similar effect as that of $\mathrm{CQ}$, reducing the $\mathrm{Cu}^{2+}-\mathrm{A} \beta_{1-42}$ oligomers by $60.3 \pm 3.5 \%$.

3.6. B10 Promotes Neuronal Neurite Outgrowth and Growth-Associated Protein 43 (GAP43), N-myc, and Microtubule-Associated Protein 2 (MAP-2) Expressions in SH-SY5Y Cells

Since differentiated SH-SY5Y cells possess similar morphology and biochemical processes to mature neurons, they were widely used to study neuronal activity [55]. In cell viability assay, B10 showed no cytotoxicity towards SH-SY5Y cells up to $25 \mu \mathrm{M}$ (Figure 6A). B10 was further evaluated for its ability to induce neurogenesis in SH-SY5Y cells.

$\mathbf{A}$

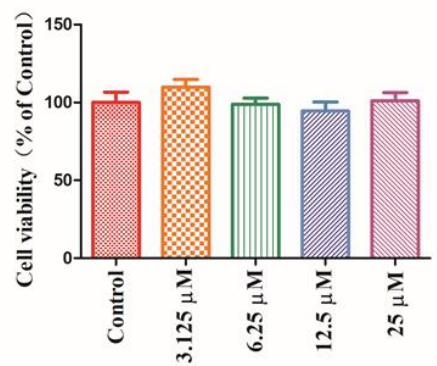

C

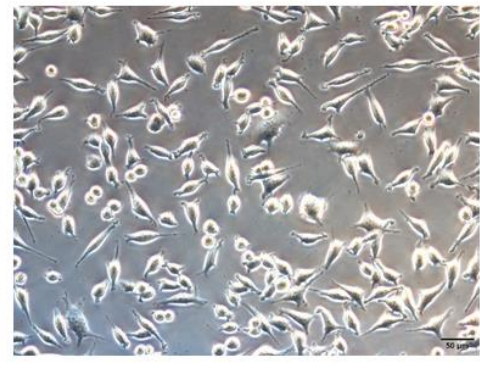

Control
B
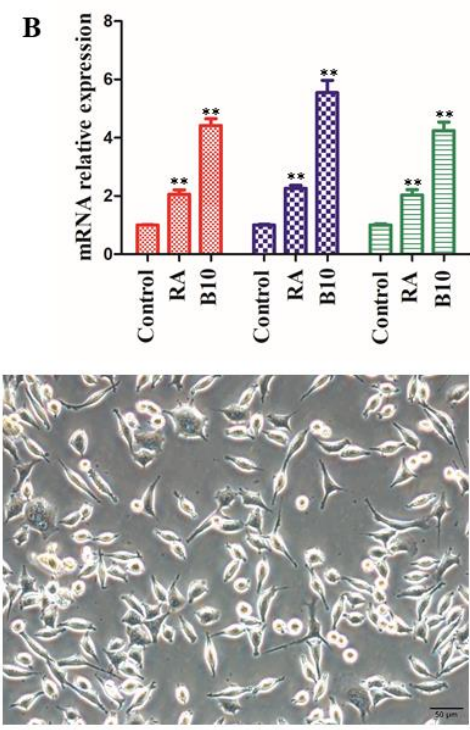

RA
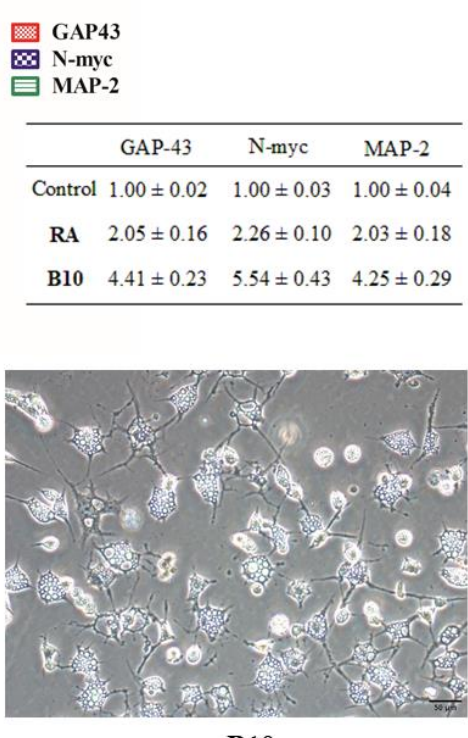

B10

Figure 6. (A) Effects of B10 on SHSY5Y cell viability, $p>0.05(\mathrm{n}=3)$; $(\mathrm{B})$ effect of B10 or RA $(10 \mu \mathrm{M})$ on neurogenesis markers expression (GAP43, N-myc and MAP-2) in SHSY5Y cells (24 h), ${ }^{* *} p<0.01$ vs. control, $\mathrm{n}=3$; (C) effects of $1 \mathrm{~B} 10$ or RA $(10 \mu \mathrm{M})$ on neurite outgrowth $(72 \mathrm{~h})$. Pictures were taken at $200 \times$ magnification.

There are several recognized biomarkers for neurogenesis, and among them, the growth-associated protein 43 (GAP-43) plays a role at synaptic level [56] and the N-myc gene is essential for normal neurogenesis and regulates cell proliferation, differentiation, and nuclear size [57], while the microtubule-associated protein 2 (MAP-2) is abundant in the mammalian nervous system and associated with the neurites and dendrite scaffold formation [58]. RA is a vitamin A metabolite that is widely used in the differentiation of SH-SY5Y cells into highly homogeneous populations of neuron-like cells [59]. After the treatment of SH-SY5Y cells with B10 or RA $(10 \mu \mathrm{M})$ for $24 \mathrm{~h}$, the mRNA expression of GAP43, N-myc, and MAP-2 was assessed by RT-PCR analysis. As shown in Figure 6B, RA induced significant expression of all the three markers. In comparison with RA, B10 exhibited more profound effects and was more than 2-fold more active than RA in promotion of the expression of GAP43, N-myc, and MAP-2 in SH-SY5Y cells. To confirm the obtained results, the morphology of the differentiated neuronal neurite outgrowth was assessed after cell treatment for $72 \mathrm{~h}$ with B10 or RA $(10 \mu \mathrm{M})$. In agreement with the RT-PCR results, B10 induced more significant neurite outgrowth than RA (Figure 6C). 


\section{Discussion}

Due to the complexity of $\mathrm{AD}$ pathogenesis, there is no effective treatment to prevent or reverse the progression of $\mathrm{AD}$, and the discovery of effective anti-AD drugs is rather challenging. In recent years, the design of a multifunctional inhibitor that target multifacet of AD was a well-accepted strategy. In this study, we designed a novel GSK-3 $\beta$ inhibitor B10 as a multitarget-directed ligand through incorporating the 8-hydroxyquinoline motif in the molecule to target $\mathrm{AD}$ metal dyshomeostasis.

GSK- $3 \beta$ is an important target for the treatment of AD because it acts as a linker between the two important histopathological hallmarks: NFTs formed by the accumulation of hyper-phosphorylated tau protein, and the extracellular senile plaques caused by abnormal $\mathrm{A} \beta$ aggregation. The overactivation of GSK-3 $\beta$ is highly related to the abnormal tau hyperphosphorylation that plays a crucial role in axonal assembly associated with synaptic transmission, neuronal degeneration and dysfunction, and NFTs. B10 was proven to be a potent GSK-3 $\beta$ inhibitor. It effectively increased the inactivated form of GSK-3 $\beta$ through the phosphorylation at Ser9 and reduced the phosphorylation of tau protein at Ser396 in SH-SY5Y cells.

$A \beta$ protein, the main component of senile plaques, is a hydrophobic, intrinsically disordered peptide with $36-43$ amino acids [60]. $A \beta$ is generated by the sequential metabolism of amyloid precursor protein by $\beta$ - and $\gamma$-secretases, and $A \beta_{1-42}$ is the most toxic and predominant species found in plaques [61]. Soluble monomeric $A \beta_{1-42}$ is prone to self-assembly to form $A \beta$ oligomers that aggregate to form protofibrils and then mature amyloid fibrils. There is increasing evidence that the soluble prefibrillar $A \beta$ oligomers are more toxic than mature fibrils [62]. Therefore, an ideal anti-AD drug should have the ability to prevent the formation as well as to disaggregate the A $\beta$ oligomers and fibrils. Though GSK-3 $\beta$ has some effect on $A \beta$ formation through its regulation of $\gamma$-secretase [32], the inhibition of GSK-3 $\beta$ may have limited effects on reducing the $A \beta$ level, considering the complicated processes in $A \beta$ formation and its clearance. In this regard, B10 is unique as a potent GSK-3 $\beta$ inhibitor that can inhibit A $\beta$ oligomers formation and promote $A \beta$ oligomers and fibrils disaggregation. As far as we know, B10 is the first potent GSK-3 $\beta$ inhibitor reported to play a direct role in A $\beta$. Molecular docking simulations revealed the binding mode of $B 10$ with $A \beta_{1-42}$ in the self-recognition hydrophobic "16 KLVFFA ${ }^{21 "}$ motif.

The homeostasis dysregulation of transition metal ions $\left(\mathrm{Cu}^{2+}, \mathrm{Zn}^{2+}\right.$, and $\left.\mathrm{Fe}^{2+}\right)$, especially $\mathrm{Cu}^{2+}$, not only promotes the aggregation and deposition of $A \beta$, but also generates ROS, leading to oxidative stress $[41,42]$. Metal chelating agents, such as $C Q$, can prevent or reverse copper-A $\beta$ interactions and reduce plaque burden in the brain of transgenic $\mathrm{AD}$ mouse models with marked improvements in cognitive performance $[63,64]$. Clinical investigations proved that $C Q$ or its derivative could improve cognitive scores and reduce $A \beta$ levels in $A D$ patients $[65,66]$. These studies suggest that targeting copper dyshomeostasis provides a choice for AD therapy. By introducing an 8-hydroxyquinoline moiety as a bidentate chelator, $\mathrm{B} 10$ selectively chelates with $\mathrm{AD}$-related metal ions, inhibits $\mathrm{Cu}^{2+}$-induced $A \beta_{1-42}$ aggregation, and promotes the disaggregation of $\mathrm{Cu}^{2+}-\mathrm{A} \beta_{1-42}$ oligomers, serving as a potent ligand to target $\mathrm{AD}$ metal dyshomeostasis.

A recent study confirms that new neurons are born throughout aging in healthy humans, but this drops sharply in $\mathrm{AD}$ patients, suggesting that therapeutic strategies aimed at increasing neurogenesis may slow the disease [67]. $\beta$-Catenin is a substrate of GSK-3 $\beta$. Phosphorylation of $\beta$-catenin in the absence of Wnt signaling by GSK3 $\beta$ results in its ubiquitination and subsequent degradation by proteasomes [68]. As a necessary transcriptional coactivator, $\beta$-catenin not only influences cellular events but also plays important roles in cell adhesion complexes, including those necessary for neuronal differentiation. The depletion of $\beta$-catenin by small interfering RNA blocked the neurite outgrowth in SH-SY5Y cells [69]. As a potent GSK- $3 \beta$ inhibitor, B10 effectively increases the $\beta$-catenin abundance, promotes neuronal neurite outgrowth, and induces significant expression of GAP43, N-myc, and MAP-2 in SH-SY5Y cells. These results are probably a combined effect of B10 on the GSK- $3 \beta$ and $\beta$-catenin signal pathways. 


\section{Conclusions}

Based on the GSK-3 $\beta$ crystal structure and through rational drug design and molecule docking simulations, we designed and screened novel pyrrolo[2,3- $b$ ]pyridine-based GSK-3 $\beta$ inhibitors with the incorporation of 8-hydroxyquinoline motif as a bidentate ligand to target AD metal dyshomeostasis as well. Compound B10 was identified as a potent GSK-3 $\beta$ inhibitor. Unlike other GSK-3 $\beta$ inhibitors reported, $B 10$ is unique and has a direct effect on $A \beta$, inhibiting the $A \beta$ oligomers formation and promoting $\mathrm{A} \beta$ oligomers and fibrils disaggregation. B10 also targets tau and metal dyshomeostasis. Moreover, B10 is more potent than RA in promoting neuronal neurite outgrowth and in inducing GAP43, N-myc, and MAP-2 expressions in SH-SY5Y cells, possibly through the GSK-3 $\beta$ and $\beta$-catenin signal pathways. Therefore, B10 could serve as a good lead for future structural optimization and further in vivo investigations as a multifunctional agent for the treatment of AD.

Author Contributions: Conceptualization, X.-L.S., N.Y. and Z.-P.L.; methodology, X.-L.S. and N.Y.; software, Y.-J.C.; validation, X.-L.S., N.Y. and Z.-P.L.; formal analysis, X.-L.S., N.Y. and Y.-J.C.; investigation, X.-L.S. and N.Y.; resources, Z.-P.L.; data curation, X.-L.S. and N.Y.; writing-original draft preparation, X.-L.S. and N.Y.; writing-review and editing, Z.-P.L.; visualization, X.-L.S. and N.Y.; supervision, Z.-P.L.; project administration, Z.-P.L.; funding acquisition, Z.-P.L. All authors have read and agreed to the published version of the manuscript.

Funding: This research was funded by the key research and development program of Shandong province (2019GSF108045 and2017CXGC1401).

Conflicts of Interest: The authors declare no conflict of interest. The funders had no role in the design of the study; in the collection, analyses, or interpretation of data; in the writing of the manuscript, or in the decision to publish the results.

\section{References}

1. Palmer, A.M. Neuroprotective therapeutics for Alzheimer's disease: Progress and prospects. Trends Pharmacol. Sci. 2011, 32, 141-147. [CrossRef] [PubMed]

2. Hardy, J. Alzheimer's disease: The amyloid cascade hypothesis: An update and reappraisal. J. Alzheimer's Dis. 2006, 9, 151-153. [CrossRef] [PubMed]

3. Zaghi, J.; Goldenson, B.; Inayathullah, M.; Lossinsky, A.S.; Masoumi, A.; Avagyan, H.; Mahanian, M.; Bernas, M.; Weinand, M.; Rosenthal, M.J.; et al. Alzheimer disease macrophages shuttle amyloid-beta from neurons to vessels, contributing to amyloid angiopathy. Acta Neuropathol. 2009, 117, 111-124. [CrossRef] [PubMed]

4. Pepeu, G.; Giovannini, M.G. Cholinesterase inhibitors and beyond. Curr. Alzheimer Res. 2009, 6, 86-96. [CrossRef] [PubMed]

5. Terry, A.V.; Buccafusco, J.J. The cholinergic hypothesis of age and Alzheimer's disease-related cognitive deficits: Recent challenges and their implications for novel drug development. J. Pharmacol. Exp. Ther. 2003, 306, 821-827. [CrossRef] [PubMed]

6. Barage, S.H.; Sonawane, K.D. Amyloid cascade hypothesis: Pathogenesis and therapeutic strategies in Alzheimer's disease. Neuropeptides 2015, 52, 1-18. [CrossRef]

7. Selkoe, D.J.; John Hardy, J. The amyloid hypothesis of Alzheimer's disease at 25 years. EMBO Mol. Med. 2016, 8, 595-608. [CrossRef]

8. Holtzman, D.M.; Carrillo, M.C.; Hendrix, J.A.; Bain, L.J.; Catafau, A.M.; Gault, L.M.; Goedert, M.; Mandelkow, E.; Mandelkow, E.-M.; Miller, D.S.; et al. Tau: From research to clinical development. Alzheimers Dementia 2016, 12, 1033-1039. [CrossRef]

9. Gao, Y.; Tan, L.; Yu, J.-T.; Tan, L. Tau in Alzheimer's disease: Mechanisms and therapeutic strategies. Curr. Alzheimer Res. 2018, 15, 283-300. [CrossRef]

10. Van der Zee, E.A.; Platt, B.; Riedel, G. Acetylcholine: Future research and perspectives. Behav. Brain Res. 2011, 221, 583-586. [CrossRef]

11. Craig, L.A.; Hong, N.S.; McDonald, R.J. Revisiting the cholinergic hypothesis in the development of Alzheimer's disease. Neurosci. Biobehav. Rev. 2011, 35, 1397-1409. [CrossRef] [PubMed]

12. Zhang, Z.-G.; Li, Y.; Ng, C.T.; Song, Y.-Q. Inflammation in Alzheimer's disease and molecular genetics: Recent update. Arch. Immunol. Ther. Exp. 2015, 63, 333-344. [CrossRef] [PubMed] 
13. Mishra, A.; Brinton, R.D. Inflammation: Bridging age, menopause and APOE $\varepsilon 4$ genotype to Alzheimer's disease. Front. Aging Neurosci. 2018, 10, 312. [CrossRef]

14. Faller, P.; Hureau, C. A bioinorganic view of Alzheimer's disease: When misplaced metal ions (re)direct the electrons to the wrong target. Chem. Eur. J. 2012, 18, 15910-15920. [CrossRef]

15. Kepp, K.P. Bioinorganic chemistry of Alzheimer's disease. Chem. Rev. 2012, 112, 5193-5239. [CrossRef]

16. Wang, X.; Wang, X.; Guo, Z. Metal-involved theranostics: An emerging strategy for fighting Alzheimer's disease. Coord. Chem. Rev. 2018, 362, 72-84. [CrossRef]

17. Li, Y.; Jiao, Q.; Xu, H.; Du, X.; Shi, L.; Jia, F.; Jiang, H. Biometal dyshomeostasis and toxic metal accumulations in the development of Alzheimer's disease. Front. Mol. Neurosci. 2017, 10, 339. [CrossRef]

18. Huang, W.J.; Zhang, X.; Chen, W.W. Role of oxidative stress in Alzheimer's disease. Biomed. Rep. 2016, 4, 519-522. [CrossRef]

19. Tramutola, A.; Lanzillotta, C.; Perluigi, M.; Butterfield, D.A. Oxidative stress, protein modification and Alzheimer disease. Brain Res. Bull. 2017, 133, 88-96. [CrossRef]

20. Agis-Torres, A.; Söllhuber, M.; Fernandez, M.; Sanchez-Montero, J.M. Multi-target-directed ligands and other therapeutic strategies in the search of a real solution for Alzheimer's disease. Curr. Neuropharmacol. 2014, 12, 2-36. [CrossRef]

21. Godyń, J.; Jończyk, J.; Panek, D.; Malawska, B. Therapeutic strategies for Alzheimer's disease in clinical trials. Pharmacol. Rep. 2016, 68, 127-138. [CrossRef] [PubMed]

22. Gong, C.X.; Liu, F.; Iqbal, K. Multifactorial hypothesis and multi-targets for Alzheimer's disease. J. Alzheimers Dis. 2018, 64, 107-117. [CrossRef] [PubMed]

23. Ramsay, R.R.; Popovic-Nikolic, M.R.; Nikolic, K.; Uliassi, E.; Bolognesi, M.L. A perspective on multi-target drug discovery and design for complex diseases. Clin. Transl. Med. 2018, 7, 1-14. [CrossRef] [PubMed]

24. Grimes, C.A.; Jope, R.S. The multifaceted roles of glycogen synthase kinase $3 \beta$ in cellular signaling. Prog. Neurobiol. 2001, 65, 391-426. [CrossRef]

25. Woodgett, J.R. Molecular cloning and expression of glycogen synthase kinase-3/factor A. EMBO J. 1990, 9 , 2431-2438. [CrossRef]

26. Leroy, K.; Brion, J.-P. Developmental expression and localization of glycogen synthase kinase- $3 \beta$ in rat brain. J. Chem. Neuroanat. 1999, 16, 279-293. [CrossRef]

27. Takashima, A. Drug development targeting the glycogen synthase kinase-3 $\beta$ (GSK-3 $\beta$ )-mediated signal transduction pathway: Role of GSK-3 $\beta$ in adult brain. J. Pharmacol. Sci. 2009, 109, 174-178. [CrossRef]

28. Hanger, D.P.; Noble, W. Functional implications of glycogen synthase kinase-3-mediated Tau phosphorylation. Int. J. Alzheimer's Dis. 2011, 2011, 1-11. [CrossRef]

29. Grundke-Iqbal, I.; Iqbal, K.; Quinlan, M.; Tung, Y.C.; Zaidi, M.S.; Wisniewski, H.M. Microtubule-associated protein tau. A component of Alzheimer paired helical filaments. J. Biol. Chem. 1986, 261, 6084-6089.

30. Grundke-Iqbal, I.; Iqbal, K.; Tung, Y.C.; Quinlan, M.; Wisniewski, H.M.; Binder, L.I. Abnormal phosphorylation of the microtubule-associated protein tau (tau) in Alzheimer cytoskeletal pathology. Proc. Natl. Acad. Sci. USA 1986, 83, 4913-4917. [CrossRef]

31. Iqbal, K.; Grundke-Iqbal, I. Discoveries of tau, abnormally hyperphosphorylated tau and others of neurofibrillary degeneration: A personal historical perspective. J. Alzheimer's Dis. 2006, 9, 219-242. [CrossRef] [PubMed]

32. Takashima, A. GSK-3 is essential in the pathogenesis of Alzheimer's disease. J. Alzheimer's Dis. 2006, 9, 309-317. [CrossRef] [PubMed]

33. Wang, H.Z.; Brown, J.; Martin, M. Glycogen synthase kinase 3: A point of convergence for the host inflammatory response. Cytokine 2011, 53, 130-140. [CrossRef]

34. Gomez-Sintes, R.; Hernandez, F.; Lucas, J.J.; Avila, J. GSK-3 mouse models to study neuronal apoptosis and neurodegeneration. Front. Mol. Neurosci. 2011, 4, 45. [CrossRef]

35. Hooper, C.; Killick, R.; Lovestone, S. The GSK3 hypothesis of Alzheimer's disease. J. Neurochem. 2008, 104, 1433-1439. [CrossRef]

36. Maqbool, M.; Mobashir, M.; Hoda, N. Pivotal role of glycogen synthase kinase-3: A therapeutic target for Alzheimer's disease. Eur. J. Med. Chem. 2016, 107, 63-81. [CrossRef]

37. O'Leary, O.; Nolan, Y. Glycogen synthase kinase-3 as a therapeutic target for cognitive dysfunction in neuropsychiatric disorders. CNS Drugs 2015, 29, 1-15. [CrossRef]

38. Llorens-Martín, M.; Jurado, J.; Hernández, F.; Ávila, J. GSK-3ß, a pivotal kinase in Alzheimer disease. Front. Mol. Neurosci. 2014, 7, 46 . 
39. Shi, X.-L.; Wu, J.-D.; Liu, P.; Liu, Z.-P. Synthesis and evaluation of novel GSK-3b inhibitors as multifunctional agents against Alzheimer's disease. Eur. J. Med. Chem. 2019, 167, 211-225. [CrossRef]

40. Ayton, S.; Lei, P.; Bush, A.I. Metallostasis in Alzheimer's disease. Free Radic. Bio. Med. 2013, 62, 76-89. [CrossRef]

41. Robert, A.; Liu, Y.; Nguyen, M.; Meunier, B. Regulation of copper and iron homeostasis by metal chelators: A possible chemotherapy for Alzheimer's disease. Acc. Chem. Res. 2015, 48, 1332-1339. [CrossRef] [PubMed]

42. Kepp, K.P. Alzheimer's disease: How metal ions define $\beta$-amyloid function. Coordin. Chem. Rev. 2017, 351, 127-159. [CrossRef]

43. Cheignon, C.; Tomas, M.; Bonnefont-Rousselot, D.; Faller, P.; Hureau, C.; Collin, F. Oxidative stress and the amyloid beta peptide in Alzheimer's disease. Redox Biol. 2018, 14, 450-464. [CrossRef] [PubMed]

44. Greenough, M.A.; Camakaris, J.; Bush, A.I. Metal dyshomeostasis and oxidative stress in Alzheimer's disease. Neurochem. Int. 2013, 62, 540-555. [CrossRef] [PubMed]

45. León, R.; Garcia, A.G.; Marco-Contelles, J. Recent advances in the multi-directed ligands approach for the treatment of Alzheimer's disease. Med. Res. Rev. 2013, 33, 139-189. [CrossRef] [PubMed]

46. Yang, C.; Zhang, X.; Wang, Y.; Yang, Y.; Liu, X.; Deng, M.; Jia, Y.; Lin, Y.; Meng, L.-H.; Zhou, Y. Discovery of a novel series of 7-azaindole scaffold derivatives as PI3K inhibitors with potent activity. ACS Med. Chem. Lett. 2017, 8, 875-880. [CrossRef]

47. Zhu, X.-F.; Zhang, J.; Sun, S.; Guo, Y.-C.; Cao, S.-X.; Zhao, Y.-F. Synthesis and structure-activity relationships study of $\alpha$-aminophosphonate derivatives containing a quinoline moiety. Chinese Chem. Lett. 2017, 28, 1514-1518. [CrossRef]

48. Leclerc, S.; Garnier, M.; Hoessel, R.; Marko, D.; Bibb, J.A.; Snyder, G.L.; Greengard, P.; Biernat, J.; Wu, Y.-Z.; Mandelkow, E.-M.; et al. Indirubins inhibit glycogen synthase kinase- $\beta$ and CDK5/P25, two protein kinases involved in abnormal tau phosphorylation in Alzheimer's disease. A property common to most cyclin-dependent kinase inhibitors? J. Biol. Chem. 2001, 276, 251-260. [CrossRef]

49. Luo, G.; Chen, L.; Burton, C.R.; Xiao, H.; Sivaprakasam, P.; Krause, C.M.; Cao, Y.; Liu, N.; Lippy, J.; Clarke, W.J.; et al. Discovery of isonicotinamides as highly selective, brain penetrable, and orally active glycogen synthase kinase-3 inhibitors. J. Med. Chem. 2016, 59, 1041-1051. [CrossRef]

50. Ikeda, S.; Kishida, S.; Yamamoto, H.; Murai, H.; Koyama, S.; Kikuchi, A. Axin, a negative regulator of the Wnt signaling pathway, forms a complex with GSK-3 $\beta$ and $\beta$-catenin and promotes GSK-3 $\beta$-dependent phosphorylation of $\beta$-catenin. EMBO J. 1998, 17, 1371-1384. [CrossRef]

51. Chen, Z.; Digiacomo, M.; Tu, Y.; Gu, Q.; Wang, S.; Yang, X.; Chu, J.; Chen, Q.; Han, Y.; Chen, J.; et al. Discovery of novel rivastigmine-hydroxycinnamic acid hybrids as multi-targeted agents for Alzheimer's disease. Eur. J. Med. Chem. 2017, 125, 784-792. [CrossRef] [PubMed]

52. Kandimalla, R.; Vallamkondu, J.; Corgiat, E.B.; Gil, K.D. Understanding aspects of aluminum exposure in Alzheimer's disease development. Brain Pathol. 2016, 26, 139-154. [CrossRef] [PubMed]

53. Rosini, M.; Simoni, E.; Bartolini, M.; Cavalli, A.; Ceccarini, L.; Pascu, N.; McClymont, D.W.; Tarozzi, A.; Bolognesi, M.L.; Minarini, A.; et al. Inhibition of acetylcholinesterase, $\beta$-amyloid aggregation, and NMDR receptors in Alzheimer's disease: A promising direction for the multi-target-directed ligands gold rush. J. Med. Chem. 2008, 51, 4381-4384. [CrossRef] [PubMed]

54. Tjernberg, L.O.; Lilliehook, C.; Callaway, D.J.; Naslund, J.; Hahne, S.; Thyberg, J.; Terenius, L.; Nordstedt, C. Controlling amyloid beta-peptide fibril formation with protease-stable ligands. J. Biol. Chem. 1997, 272, 12601-12605. [CrossRef]

55. Agholme, L.; Lindström, T.; Kågedal, K.; Marcusson, J.; Hallbeck, M. An in vitro model for neuroscience: Differentiation of SHSY5Y cells into cells with morphological and biochemical characteristics of mature neurons. J. Alzheimers Dis. 2010, 20, 1069-1082. [CrossRef]

56. Parrow, V.; Fagerstrom, S.; Meyerson, G.; Nanberg, E.; Pahlman, S. Protein kinase C-alpha and -epsilon are enriched in growth cones of differentiating SH-SY5Y human neuroblastoma cells. J. Neurosci. Res. 1995, 41, 782-791. [CrossRef]

57. Knoepfler, P.S.; Cheng, P.F.; Eisenman, R.N. N-myc is essential during neurogenesis for the rapid expansion of progenitor cell populations and the inhibition of neuronal differentiation. Genes Dev. 2002, 16, 2699-2712. [CrossRef] 
58. Snchez Martin, C.; Ledesma, D.; Dotti, C.G.; Avila, J. Microtubule-associated protein-2 located in growth regions of rat hippocampal neurons is highly phosphorylated at its proline-rich region. Neuroscience 2000, 101, 885-893. [CrossRef]

59. Encinas, M.; Iglesias, M.; Liu, Y.; Wang, H.; Muhaisen, A.; Cena, V.; Gallego, C.; Comella, J.X. Sequential treatment of SH-SY5Y cells with retinoic acid and brain-derived neurotrophic factor gives rise to fully differentiated, neurotrophic factor-dependent, human neuron-like cells. J. Neurochem. 2000, 75, 991-1003. [CrossRef]

60. Qiang, W.; Yau, W.M.; Lu, J.X.; Collinge, J.; Tycko, R. Structural variation in amyloid-beta fibrils from Alzheimer's disease clinical subtypes. Nature 2017, 541, 217-221. [CrossRef]

61. Chiti, F.; Dobson, C.M. Protein misfolding, amyloid formation, and human disease: A summary of progress over the last decade. Annu. Rev. Biochem. 2017, 86, 27-68. [CrossRef] [PubMed]

62. Cleary, J.P.; Walsh, D.M.; Hofmeister, J.J.; Shankar, G.M.; Kuskowski, M.A.; Selkoe, D.J.; Ashe, K.H. Natural oligomers of the amyloid-beta protein specifically disrupt cognitive function. Nat. Neurosci. 2005, 8, 79-84. [CrossRef] [PubMed]

63. Cherny, R.A.; Atwood, C.S.; Xilinas, M.E.; Gray, D.N.; Jones, W.D.; McLean, C.A.; Barnham, K.J.; Volitakis, I.; Fraser, F.W.; Kim, Y.; et al. Treatment with a copper-zinc chelator markedly and rapidly inhibits beta-amyloid accumulation in Alzheimer's disease transgenic mice. Neuron 2001, 30, 665-676. [CrossRef]

64. Adlard, P.A.; Cherny, R.A.; Finkelstein, D.I.; Gautier, E.; Robb, E.; Cortes, M.; Volitakis, I.; Liu, X.; Smith, J.P.; Perez, K.; et al. Rapid restoration of cognition in Alzheimer's transgenic mice with 8-hydroxy quinoline analogs is associated with decreased interstitial A $\beta$. Neuron 2008, 59, 43-55. [CrossRef] [PubMed]

65. Ritchie, C.W.; Bush, A.I.; Mackinnon, A.; Macfarlane, S.; Mastwyk, M.; MacGregor, L.; Kiers, L.; Cherny, R.; Li, Q.-X.; Tammer, A.; et al. Metal-protein attenuation with iodochlorhydroxyquin (clioquinol) targeting A $\beta$ amyloid deposition and toxicity in Alzheimer disease: A pilot phase 2 clinical trial. Arch. Neurol. 2003, 60, 1685-1691. [CrossRef] [PubMed]

66. Lannfelt, L.; Blennow, K.; Zetterberg, H.; Batsman, S.; Ames, D.; Harrison, J.; Masters, C.L.; Targum, S.; Bush, A.I.; Murdoch, R.; et al. Safety, efficacy, and biomarker findings of PBT2 in targeting A $\beta$ as a modifying therapy for Alzheimer's disease: A phase Ila, double-blind, randomised, placebo-controlled trial. Lancet Neurol. 2008, 7, 779-786. [CrossRef]

67. Moreno-Jiménez, E.P.; Flor-García, M.; Terreros-Roncal, J.; Rábano, A.; Cafini, F.; Pallas-Bazarra, N.; Ávila, J.; Llorens-Martín, M. Adult hippocampal neurogenesis is abundant in neurologically healthy subjects and drops sharply in patients with Alzheimer's disease. Nat. Med. 2019, 25, 554-560. [CrossRef]

68. Shimizu, H.; Julius, M.A.; Giarre, M.; Zheng, Z.; Brown, A.M.; Kitajewski, J. Transformation by Wnt family proteins correlates with regulation of $\beta$-catenin. Cell Growth Differ. 1997, 8, 1349-1358.

69. Lin, C.-C.; Chou, C.-H.; Howng, S.-L.; Hsu, C.-Y.; Hwang, C.-C.; Wang, C.; Hsu, C.-M.; Hong, Y.-R. GSKIP, an inhibitor of GSK3 $\beta$, mediates the N-cadherin/ $\beta$-catenin pool in the differentiation of SH-SY5Y cells. J. Cell. Biochem. 2009, 108, 1325-1336. [CrossRef]

(C) 2020 by the authors. Licensee MDPI, Basel, Switzerland. This article is an open access article distributed under the terms and conditions of the Creative Commons Attribution (CC BY) license (http://creativecommons.org/licenses/by/4.0/). 